Юрий Андреевич ЛАБЫНЦЕВ 


\section{КНИЖНОЕ НАСЛЕДИЕ ФРАНЦИСКА СКОРИНЫ ${ }^{1}$}

\section{Аннотация:}

Статья посвящена оценке значения книжно-литературного наследия доктора наук Франциска Скорины (XVI в.) и распространению изданий этого великого белорусского просветителя в славянском мире.

\section{Ключевые слова:}

Франциск Скорина, белорусская литература, библеистика, славистика.

Abstract: Y.A. LabyntSev “The literary heritage of Francysk Skarina”.

The article is devoted to the assessment of the value of the literary heritage of the doctor Francysk Skarina (16th century) and the distribution of publications of this great Belarusian educator in the Slavic world.

\section{Keywords:}

Francysk Skarina, Belarusian literature, biblical studies, Slavistics.

Поктор Франциск Скорина - один из самых выдающихся культурных деятелей славянства, писатель, издатель, переводчик, национальная гордость белорусского народа. Франциск Скорина - писатель-философ, писатель-гуманист, выступивший перед своим народом с яркими патриотическими воззваниями, и одновременно глубокий психолог, лирик, сумевший рассказать людям о величайших тайнах мира. Франциск Скорина доверил бумаге такие свои сокровенные, выстраданные мысли, которые читаются сейчас как некая абсолютная законченная формула духовного развития человека: «сть наивышшая мудрость розмышление смерти и познание самого себе»²; «Наиболей любовь ко всим да соблудает, еже есть совершена над все иные дарования, без нея же ничто проспешно есть» ${ }^{3}$.

Средством и инструментом пропаганды этой земной всечеловеческой любви Скорина избрал печатную книгу, доступную его братьям на Руси благодаря хорошо понятному языку и значительным тиражам. И как завет всем созидающим Книгу, писателям будущего и самому себе прозвучали слова просветителя: «Також и мы братия не можем ли во великих послужити посполитому люду рускаго языка, сие малые книжки праци нашее

\footnotetext{
1 Работа выполнена при финансовой поддержке РФФИ (грант № 18-512-76004).

2 Предъсловие в книгу Иов // Книга Иова. Прага, 1517. 10 сентября. Л. 2 об.

3 Коринфом перваго послания светого апостола Павла сказание доктором Франциском Скориною с Полоцка // Апостол. Вильна, март 1525. Л. 36 об. третьего счета.
} 


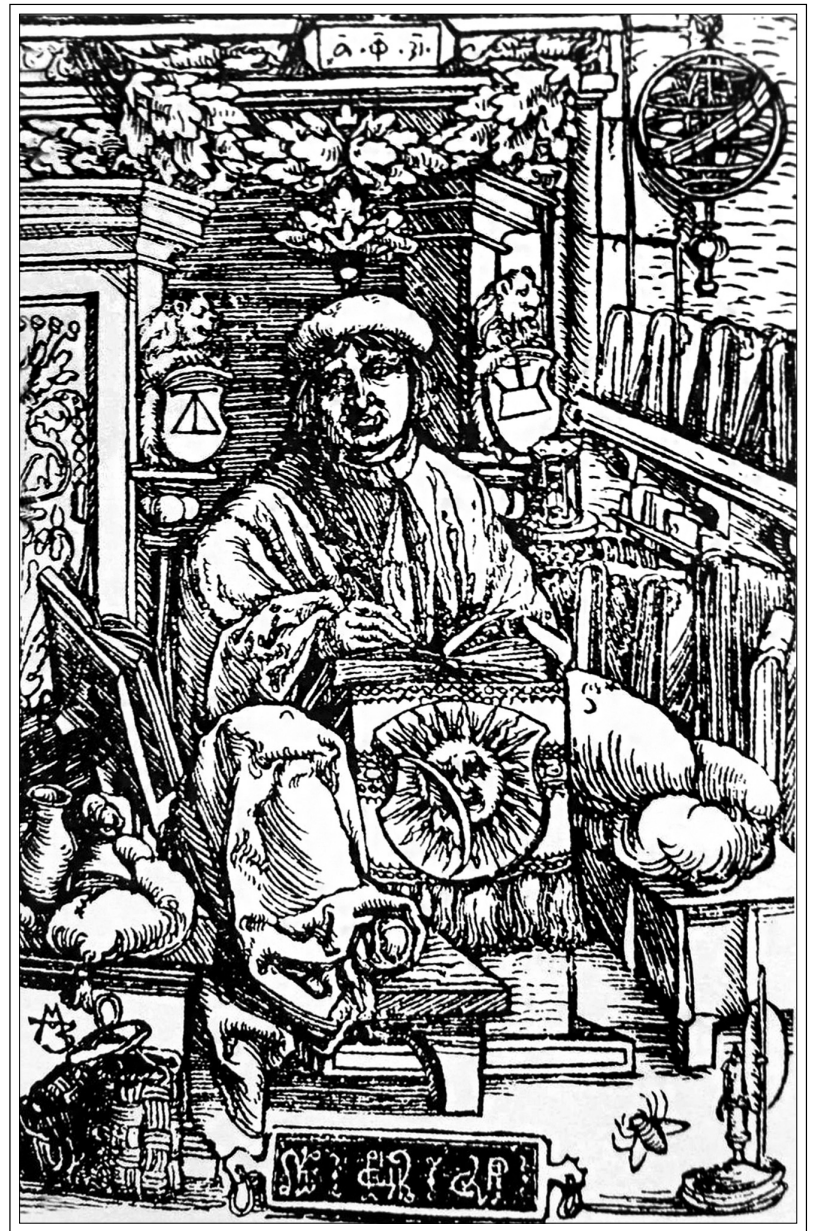

Портрет

доктора Франииска Скорины

(гравюра 1517 г.)

приносимо им» ${ }^{4}$ «Да совершен будет человек» - вслед за авторитетами древности восклицал Франциск Скорина 5 . Он стремился сделать все, чтобы его народ на родном языке мог постичь сокровенную мудрость человечества.

Как выдающийся европеец-гуманист Скорина страстно желал послужить общему делу духовного возрождения человека, его внутреннему совершенствованию. Этому и посвящены книги великого белоруса, вос-

4 Предословие доктора Франъциска Скорины с Полоцька во книги Леувит Моисеевы // Книга Левит. Прага, около 1519. Л. 2 об.-3.

5 Предословие в Псалтирь // Псалтырь. Прага, 6 августа 1517 г. Л. 2. 
принимающиеся сейчас как самая дорогая национальная реликвия, как духовное сокровище, национальная святыня, как символ всей тысячелетней белорусской культуры. Наряду с многими книгами, в том числе им самим написанными, Скорина издал в своем переводе значительную часть Библии. Она стала первой печатной Библией у восточно- и южнославянских народов и вышла в свет почти за полстолетия до появления польских печатных Библий.

За свою жизнь Скорина объездил немало стран, учился в старейших европейских университетах, достиг высших ученых степеней, был доктором «семи свободных искусств» и доктором медицины. Все это дало ему возможность, как никому другому у восточных славян, сопоставить жизненные ценности Запада и Востока Европы, решить для себя и других, прежде всего для «братьев» своих «Руси», те многочисленные философско-гуманитарные, богословские и литературные проблемы, которые и сегодня не утратили своей в важноси.

В силу исторических условий, в отличие от западноевропейских гуманистов, Скорина должен был весьма считаться с особой, веками узаконенной восточнославянской книжной традицией, которую, тем не менее, он значительно реформировал. Невозможность отойти в своем литературном творчестве на традиционном церковнославянском языке и даже на языке, близком к народному, от этой традиции (иначе он не был бы понят соотечественниками-современниками), вынуждала Скорину максимально опираться на нее, часто высказывать свои собственные суждения устами известных древних авторитетов. Использование в творчестве чисто традиционных восточных начал и сплав их с западными дали необычайно интересный, оригинальнейший литературно-графический материал, который при его рассмотрении ставит в тупик не только современника Скорины, но и современного ученого. Рождающийся художественный образ заставляет одновременно помнить и о литературных особенностях Востока, и о достижениях графического искусства Запада, и о той общности культур, которая свойственна всей Европе. Вот почему невозможно отделить в творчестве Скорины эти две главнейшие европейские культурные традиции: традицию византийского Востока и традицию римского, латинского Запада. Франциск Скорина связал, замкнул их в своем творчестве. Об этом свидетельствуют не только сами тексты книг печатника, но и их архитектоника, композиция, графика.

Величайшая заслуга Скорины состоит в том, что он предназначает свои издания и сочинения не узкому кругу образованных лиц, пишет для них не на латинском языке, как это делает, например, Эразм Роттердамский, a, используя в основном традиционные литературные жанры и близкий к народному язык, создает народноязычные издания, предназначавшиеся всем людям без исключения. Книги Скорины - «четьи» - подобные тем, что легли в основание многих европейских национальных литератур, имели конкретный читательский адрес. 
Выпущенные им книги - это не просто переведенные или подготовленные к печати тексты, снабженные теми или иными комментариями. Они представляют собой сложный комплекс сотен самых различных литературных произведений, которые были написаны, переведены или подготовлены им к изданию по канонам тогдашней европейской науки. Как мастер слова Скорина предстает перед нами сразу в нескольких авторских ипостасях: писатель-прозаик, гимнограф и поэт, переводчик с нескольких древних и новых языков.

Книги Франциска Скорины выступают как единство содержания и его типографского воплощения, которое служит своеобразным фоном и обрамлением главного в книге - слова, написанного или переведенного просветителем. Эта неразрывная связь прослеживается на всех уровнях, на примере всех элементов книг Скорины, включая даже мельчайшие. Почти одинаково важны и титульный лист, и предисловия, и надписания глав, и основной текст, и колофон, и все типографские и графические элементы, начиная со шрифтов и до гравюр, а также приемы набора и верстки, манера подачи материала, компоновка страниц, использование краски черного и красного цветов. Необходимо понимать и помнить, что книги Скорины - это именно единство, нерасторжимое и неделимое. В слиянии искусства словесного, графического и типографского он достиг величайшего совершенства, создал столь простую и совершенную гармонию слова и его материального, книжного, печатного воплощения, к которой в новейшее время так страстно стремились европейские модернисты и русские символисты.

Скорина-прозаик работал во многих жанрах. Одни из них являлись у нас традиционными, другие, а их было едва ли не большинство, он впервые ввел в белорусскую, да и во все восточнославянские литературы.

Сравнивая творения Скорины с творчеством его виднейших европейских современников, нельзя не отметить, что в отличие от многих из них он значительно опередил свое время и сознание родного народа. Лишь спустя столетия Скорину назовут великим, он станет символом всей белорусской культуры. Скорину мы ценим за то, что литература на родном языке оказалась для него средством, целью и тем абсолютом, который мог указать людям истинный путь в жизни.

Славянский мир еще при жизни Ф. Скорины во многом по достоинству оценил его деятельность. Несмотря на аканоничность переведенной и напечатанной им Библии, она получила широкую известность на Востоке Европы, преимущественно, у белорусов, русских, украинцев и славян, живущих в отрогах Карпат. Можно говорить также о прямом влиянии Скорининской библии на украинскую литературу и прежде всего на украинские библийные издания и рукописи, включая новозаветные. Поражают широта распространения и популярность книг Ф. Скорины в Московской Руси и России. Именно в России произведениям Ф. Скорины суждена была наиболее долгая жизнь в читательской среде. Русские же старообрядцы пере- 
писывали и даже перепечатывали созданные им тексты вплоть до начала ХХ столетия.

Можно говорить и об особой авторитетности наследия Ф. Скорины среди протестантов Европы. Его книги оказали прямое влияние на Приможа Трубера, Симона Будного и деятельность известного Ильи Копиевича, сподвижника Петра I. В этой связи интересна оценка Ф. Скорины, данная ему в начале XVII в. таким авторитетом греко-католической (униатской) церкви, как Анастасий Селява, настоятель Виленского Свято-Троицкого базилианского монастыря: «<...> Скорина, по вероисповеданию гусит, который напечатал вам книги по руски в Праге. Принимали их с благодарностью, еще бы, ведь он называл себя Русином с Полоцка. Восхваляли между собой его издания, человек достойный, говорили, и Русин, брат наш это печатал» ${ }^{6}$.

Примечательно, что у восточных славян книги Ф. Скорины читали не только представители элиты, но и крестьяне. Примеров здесь много, особенно если иметь ввиду русское старообрядчество, благодаря которому до нас дошла значительная, если не большая часть экземпляров изданий Ф. Скорины.

Едва ли не самый яркий пример авторитетности литературного наследия Ф. Скорины для современников демонстрирует знаменитое украинское Пересопницкое Евангелие 1556-1561 гг, на котором ныне присягают вступающие в должность президенты Украины. Евангелие это, написанное на Волыни, создано под непосредственным влиянием Скорининской библии ${ }^{7}$. Пожалуй, настоящую традицию составляет использование скорининского наследия в кругу старообрядчества. При этом Ф. Скорина выступает как авторитет древности, и на него в наиболее важных при доказательстве собственной правоты случаях ссылаются виднейшие представители старообрядчества различных согласий. Находим мы ссылки на издания Ф. Скорины и в известных «Поморских ответах», созданных в глуши Русского Севера на старообрядческом Выгу в начале XVIII в.

Гуманитарная наука обратила пристальное внимание на издания Ф. Скорины, пожалуй, лишь на исходе XVIII столетия, хотя С. Рингельтаубе называл его «мастером слова» уже в $1744 \Gamma^{8}$ Приоритет здесь принадлежит П. Алексееву, И. Штритеру, Д. Семенову-Рудневу (епископу Дамаскину), Й. Добровскому. Тем не менее еще и в середине XIX в. М. Погодин имел все основания утверждать, что скорининское наследие никто у нас должным образом «не изучает» 9 . Книги Ф. Скорины были и оставались гордостью

6 Anastazy Sielawa. Antelenchus, to iest Odpis... Wilna, 1622. S. 53.

7 Владимиров П.В. Доктор Франциск Скорина: Его переводы, печатные издания и язык. СПб., 1888. С. 234-237.

8 Ringeltaube S. Gründliche Nachricht von polnischen Bibeln... Danzig, 1744. S. 170.

9 Погодин М. О приобретениях на Нижегородской ярмарке // Московитянин. 1847. Ч. 3. C. 120-122. 
«каждой библиотеки», как о том сообщалось в первом по времени отчете Московского публичного музея 1864 г. ${ }^{10}$, но широкого и всестороннего их изучения все же не проводилось вплоть до появления в 1888 г. монографии П. Владимирова. Тогда же разгорелся жаркий спор о конфессиональной принадлежности Ф. Скорины, причем первоначально появилось множество публикаций о католической ориентации белорусского просветителя ${ }^{11}$. Пожалуй самая взвешенная оценка тех лет, остающаяся во многом справедливой и сейчас, принадлежала украинскому литературоведу А. Барвинскому, который считал Ф. Скорину в этом плане личностью «загадочной»12, в то время как его земляки-львовяне писали о Ф. Скорине - «православном русине» ${ }^{13}$ или же Скорине-«католике» ${ }^{14}$.

Постепенно Ф. Скориной начало гордиться все ученое славянство вне зависимости от вероисповедных симпатий, хотя разноголосица мнений относительно «связи его деятельности с какою-либо религиозной доктриной», как о том упоминал украинский историк М. Грушевский ${ }^{15}$, не стихает и поныне. Книги Скорины получили широчайшее распространение во всех восточнославянских православ-

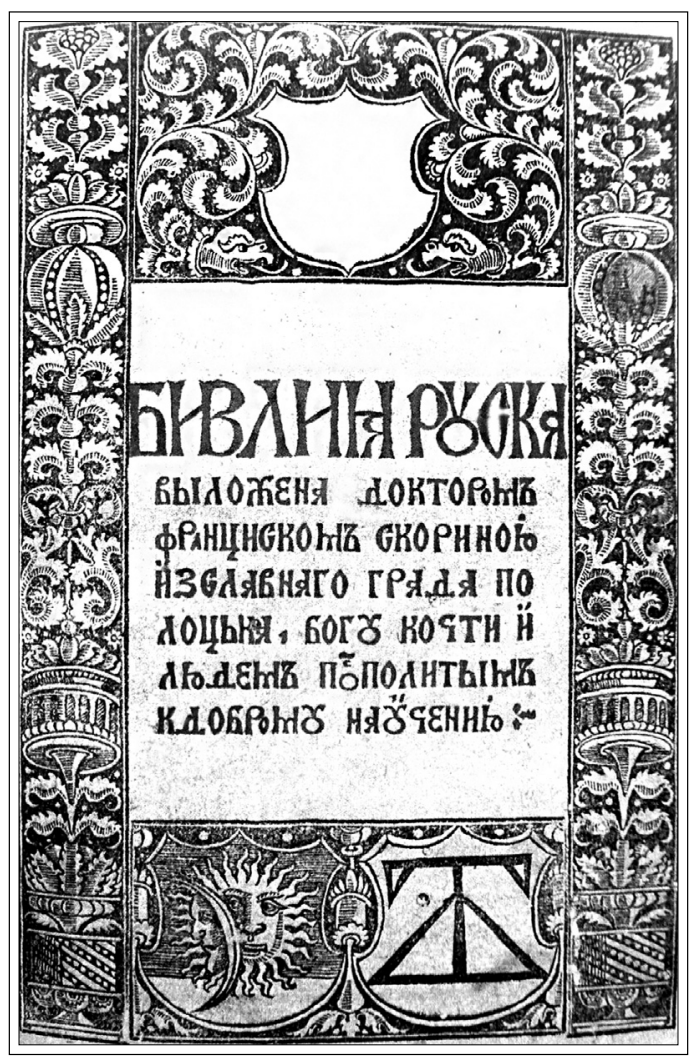

Титульный лист

издания Франциска Скорины

«Бивлия руска»

(Прага, 1517-1519)

10 Отчет по Московскому публичному музею от времени основания его до 1 января 1864 г. СПб., 1864. С. 31.

11 Белорусс. Судьбы русского языка в костелах Северо-Западного края // Русский вестник. 1868. № 9. С. 143-144; Козловский И. Библиографические редкости, хранящиеся в Виленской публичной библиотеке // Вестник Западной России. 1870. Т. 1. Кн. 3. С. 89; Василевский В.Ф. Очерк истории города Вильны // Памятники русской старины в западных губерниях империи. СПб, 1872. Вып. 5. С. 33.

12 Ол.Б. Библиография // Правда. 1879. № 9. С. 590-592.

13 Вахнянин А. О докторе Франциску Скорине и его литературной деятельности. Львов, 1879.

14 Ю. П. Килька уваг.. // Правда. 1879. № 10. С. 640-645.

15 Грушевсьжий М. Історія Україны-Руси. Київ-Львів, 1907. Т. 6. С. 428. 
ных землях, а его гимнографические сочинения со временем включили в свои сборники даже русские старообрядцы. Деятели Реформации, в частности Симон Будный, считали Скорину одним из своих предшественников. Последний неоднократно ссылался на скорининскую «Бивлию руску». Католики, а за ними и греко-католики (униаты), постоянно критиковали Скорину и его «Бивлию», называя ее издателя «еретиком-гуситом». Подобная неоднородность, а порой и противоположность в трактовках деятельности и взглядов Скорины объясняется не только конкретными конфессиональными установками тех или иных лиц и всего их лагеря в целом, но и тем, что Скорина творил в период особого исторического момента в судьбах Slavia Byzantina и Slavia Romana на пограничье этих двух великих европейских культурных традиций. По сей день литературное, философское и богословское наследие Скорины все еще остается недостаточно изученным. Об этом признанном гении славянского мира, гордости и символе белорусской национальной культуры до сих пор не создана исчерпывающая научная библиография. Именем Скорины названы проспекты и улицы белорусских городов, учебные заведения; в Белоруссии и за рубежом Скорине установлены памятники; учреждены белорусские государственный «скорининские» награды.

\section{ЛИТЕРАТУРА}

Анічәнка УВ. Слоўнік мовы Скарыны. Мінск, 1977-1994. Т. 1-3.

Апостол. Вильна, март 1525. 344 л.

Белорусс. Судьбы русского языка в костелах Северо-Западного края // Русский вестник. 1868. № 9. С. 143-144.

Белорусский просветитель Франциск Скорина и начало книгопечатания в Белоруссии и Литве. М., 1979. 279 с.

Василевский В.Ф. Очерк истории города Вильны // Памятники русской старины в западных губерниях империи. СПб., 1872. Вып. 5. С. 9-80.

Вахнянин А. О докторе Франциску Скорине и его литературной деятельности. Львов, 1879. 22 с.

Владимиров П.В. Доктор Франциск Скорина: Его переводы, печатные издания и язык. СПб., 1888. XXVI, 351, [12] с.

Галенчанка ГЯ. Францыск Скарына - беларускі і ўсходнеславянскі першадрукар. Мінск, 1993. 280 с.

Грушевсъкий М. Історія Україны-Руси. Київ-Львів, 1907. Т. 6. 670 с.

Книга Иова. Прага, 1517, 10 сентября. 52 л.

Книга Левит. Прага, около 1519.54 л.

Кніжная спадчына Франціска Скарыны. Мінск, 2013-2017. Т. 1-20.

Кніжная спадчына Франціска Скарыны: Вяртанне. Мінск, 2017. 195 с.

Козловский И. Библиографические редкости, хранящиеся в Виленской публичной библиотеке // Вестник Западной России. 1870. Т. 1. Кн. 3. С. 85-102.

Лабынцаў Ю. Пачатае Скарынам. Мінск, 1990. 333 с.

Лабыниаў Ю. Скарынаўскі каляндар. Выд. 2-е. Мінск, 1990. 184 с. 
Лабынщев ЮА. Непреходящие споры о Франциске Скорине, включая «беловежские», и необходимость подготовки новейшей библиографии работ о нем // Białorutenistyka Białostocka. T. 10. Białystok, 2018. S. 9-23.

Матэрыялы Міжнароднага кангрэса «500 гадоў беларускага кнігадрукавання». Мінск, 2017. Ч. 1-2.

Немировский ЕЛ. Франциск Скорина: жизнь и деятельность белорусского просветителя. Минск, 1990.597 с.

Ол.Б. Библиография // Правда. 1879. № 9. С. 590-592.

Отчет по Московскому публичному музею от времени основания его до 1 января 1864 г. СПб., 1864. 178 с.

Погодин М. О приобретениях на Нижегородской ярмарке // Московитянин. 1847. Ч. 3. С. $120-122$.

Подокшин СА. Франциск Скорина. М., 1981. 216 с.

Псалтырь. Прага, 6 августа 1517 г. 142 л.

Суша АА. Франциск Скорина - человек мира. Минск, 2016. 303 с.

Франциск Скорина и его время: Энциклопедический справочник. Минск, 1990. $631 \mathrm{c}$.

Францыск Скарына: Асоба, дзейнасць, спадчына. Мінск, 2017. 293, 2 с.

Францыск Скарына: новыя даследаванні. Мінск, 2019. 215 с.

Францыск Скарына: Энцыклапедыя. Мінск, 2017. 568 с.

Шматов В.Ф. Искусство книги Франциска Скорины. М., 1990. 207 с.

Ю. П. Килька уваг... // Правда. 1879. № 10. С. 640-645.

Anastazy Sielawa. Antelenchus, to iest Odpis... Wilna, 1622. $66 \mathrm{s.}$

Franciszek Skoryna z Połocka: Życie i pisma / M. Walczak-Mikołajczakowa, A. Naumow. Gniezno, 2007.232 s.

Nemirovskij EL. Gesamt katalog der Frühdrucke in kyrillischer Schrift. Bd. 5. Die Druckerei von Francisk Skorina in Wilna. Baden-Baden, 1999. $263 \mathrm{~s}$.

Nemirovskij E.L. Gesamt katalog der Frühdrucke in kyrillischer Schrift. Bd. 3. Die Prager Druckerei von Francisk Skorina. Baden-Baden, 1998. 405 s.

Ringeltaube S. Gründliche Nachricht von polnischen Bibeln... Danzig, 1744. 32, 348, 20 s. 